\title{
Sorption properties of granulometric fractions in Haplic Cambisol developed from boulder loam
}

\begin{abstract}
The aim of the paper was to investigate the sorption properties of granulometric fractions separated from the genetic horizons of arable Haplic Cambisol developed from boulder loams of the Middle-Polish (Riss) Glaciation, Wartanian Stadial (central Poland). Separation of granulometric fractions was made with application of the Atterberg method without the use of centrifuging and dispersing agents. The cation exchange capacity average value in $\mathrm{cmol}(+) \mathrm{kg}^{-1}$ and $\%$ contribution in particular fractions reached: $1-0.1 \mathrm{~mm}-2.1(1.6 \%), 0.1-0.05 \mathrm{~mm}-5.5(4.0 \%), 0.05-0.02 \mathrm{~mm}-8.5(6.1 \%), 0.02-0.01 \mathrm{~mm}-13.0(10.1 \%), 0.01-0.005 \mathrm{~mm}-$ $16.1(12.8 \%), 0.005-0.002 \mathrm{~mm}-28.6(20.5 \%)$ and fraction $<0.002 \mathrm{~mm}-48.7(44.9 \%)$. Leaching of the total exchangeable bases was the largest in the $0.1-0.05 \mathrm{~mm}$ fraction and decreased successively with decreasing grain diameter. Sorption properties of the tested soil determine its high agricultural value and buffer properties. The cation exchange capacity of the recognised granulometric fractions successively increased with decrease of their diameter while leaching process intensity in individual fractions decreased gradually as their dimensions decreased. Calcium was the most leached cation, followed by magnesium and sodium, whereas potassium was not leached at all. Significant increase of the cation exchange capacity in fractions from carbonate horizons was mostly caused by the increased contribution of calcium, which could be released from carbonates during extraction of bases.
\end{abstract}

Keywords: granulometric fractions, cation exchange capacity, leaching process

\section{INTRODUCTION}

Studies of the properties of granulometric fractions are very important, because they allow for a thorough recognition of the influence of the granulometric composition of soils on their physical (Brogowski and Kwasowski 2015; Francaviglia et al. 2016, Kozłowski and Komisarek 2017b; Malik et al. 2014, Rafraf et al. 2016), chemical (Czaban et al. 2014, Rastegari et al. 2016, Skic et al. 2016), and biological properties (Stemmer et al. 1998), and their effect on pedogenic processes (Kozłowski and Komisarek 2017a; Musztyfaga and Kabała 2015). Of particular importance are further investigations on the sorption properties of granulometric fractions with regard to the recognition of processes of sorption and desorption of macro- and microelements indispensable for plants, and of harmful heavy metals (Dąbkowska-Naskręt et al. 2016, Roth et al. 2012) and other hazardous compounds (Korobova et al. 2014). The results of these studies may be used in effective environmental protection by restricting the mobility of harmful elements and substances in the environment and in consequence preventing their entering in the food chain. So far, the investigations were focused on the sorption properties of granulometric fractions (Asadu et al. 1997, Okołowicz 1996), their mineral composition (Morrás 1995, Soares et al. 2005) and processes of weathering on the surfaces (ultrastructure) of mineral grains they are composed of (Brogowski and Kocoń 1984; Morrás 1995). Polish and international soil science literature reveals an abundance of results obtained during studies of the sorption properties determined in the bulk soil mass as the basic analytical procedure (Chojnicki 2002, Kalembasa et al. 2011), whereas there are relatively very few reports on the sorption capacity of particular granulometric fractions (Asadu et al. 1997, Okołowicz 1996). One of the reasons of such discrepancy is the fact that distinguishing particular granulometric fractions from the soil solid phase, particularly without the use of centrifuging and peptizers, is a time and labour consuming procedure.

This study was focused on testing the sorption properties of particular granulometric fractions, selected from the genetic horizons of Haplic Cambisol, an arable soil developed from boulder loams, representing fertile soils used in agriculture and making up about $30 \%$ of the arable soils in Poland. More detailed recognition of the sorption properties of these soils may be used for their more reasonable agricultural usage (such as mineral fertilization) and 
increase of the possibility of accumulation and immobilization of hazardous elements, chemical compounds and active pesticide substances (Martins et al. 2018, Singh et al. 2014).

\section{MATERIALS AND METHODS}

According to the FAO-WRB classification (IUSS Working Group WRB 2015), the studied soil was determined as Haplic Cambisol (Dystric) developed from boulder loams of the Middle-Polish (Riss) Glaciation, Wartanian Stadial. It is located in Gąbin near Płock (central Poland: $52^{\circ} 23^{\circ} 43.7^{\prime \prime N}-$ $\left.19^{\circ} 45^{\prime} 20.4 " \mathrm{E}\right)$.

Fieldwork comprising measuring and description of the soil profile, and sample collection from particular genetic horizons was made in accordance with the methodology of Jahn et al. (2006). Separation of granulometric fractions was made with application of the Atterberg method (USDA SCS 1992) without using chemical compounds for peptization. Peptization was carried out using thermal-mechanical methods by boiling the soil with redistilled water $(0.5 \mathrm{~h})$ and then mixing with a rotary mixer for about $10 \mathrm{~min}$. Boiling and mixing was performed till the entire $<0.002 \mathrm{~mm}$ fraction was separated. Similarly, however without boiling, the $>0.002 \mathrm{~mm}$ fraction was separated, whereas the 1 to $0.1 \mathrm{~mm}$ fractions were sieve-separated after drying. The separated fractions were dried on evaporating dishes in a water bath and then dried completely in a dryer at $80-90^{\circ} \mathrm{C}$. After drying and weighing, the percentage content of the particular fractions in the studied soil was calculated.

The following properties were determined in the soil: total organic carbon (TOC) using the Tiurin method, $\mathrm{pH}$ in distilled water and $1 \mathrm{M} \mathrm{KCl}$, using the potentiometer method at a soil:liquid ratio of $1: 2.5(\mathrm{v} / \mathrm{v})$, and the calcium carbonate equivalent using the volumetric method using a Scheibler apparatus (van Reeuwijk, 1992). The following properties were determined in the fractions and in the soil: total potential acidity $\left(\mathrm{H}^{+}\right)$using the Kappen method (extraction using $1 \mathrm{~mol} \cdot \mathrm{dm}^{-3}$ calcium acetate and titration using $\left.0.1 \mathrm{~mol} \cdot \mathrm{dm}^{-3} \mathrm{NaOH}\right)$, total exchangeable base cations $\left(\mathrm{Ca}^{2+}, \mathrm{Mg}^{2+}, \mathrm{K}^{+}, \mathrm{Na}^{+}\right)$using $1 \mathrm{M}$ ammonium acetate at $\mathrm{pH}=7$ (in samples with carbonates using $1 \mathrm{M}$ ammonium chloride at $\mathrm{pH}=8.2$ ) and analysed by an atomic absorption spectrometer (Thermoelemental SOLAAR M6). The cation exchange capacity (CEC) and base saturation (BS) were calculated based on the sum of total exchangeable base cations (TEB) and potential acidity $\left(\mathrm{H}^{+}\right)$. For statistical evaluation of results analysis of regression was applied.

\section{RESULTS}

To the depth of $50 \mathrm{~cm}$ the studied soil is sandy loam passing into clay loam deeper in the soil profile (Table 1). The surface horizons are dominated by the fine sand fraction $(0.25-0.1 \mathrm{~mm})$, whereas the deeper horizons are dominated by the clay fraction $(<0.002 \mathrm{~mm})$. Acidic reaction in the surface horizons changes into neutral in the deepest parts of the soil profile, similarly as the saturation of the sorption complex by alkaline cations (BS) which increases with depth (Table 2). The highest total organic carbon (TOC) content occurs in the humus horizon and gradually decreases inwards. The cation exchange capacity is the lowest in the surface horizons, whereas it shows the highest values in the deepest part of the profile containing carbonates and is related to the granulometric composition of the soil.

Cation exchange capacity depends on the soil granulometric composition, precisely on the contribution of particular fractions and their mineral composition, the content of humus compounds, and iron and aluminium oxides.

The content of exchangeable calcium increases with diminishing size of the soil particles from sand to clay. It is generally sorbed by the clay fraction $<0.002 \mathrm{~mm}$, which averagely binds $55.1 \%$ of this element (Fig. 1) in the range of 27.4 to $78.4 \%$ (Table 3). The particular fractions bind calcium averagely at: 1 to $0.1 \mathrm{~mm}-1.4 \%, 0.1$ to $0.02 \mathrm{~mm}-9.0 \%$ and 0.02 to $0.002 \mathrm{~mm}-34.4 \%$. In the soil profile the relatively large content of exchangeable calcium in all fractions of the humus horizon is most probably the effect of bioaccumulation. The lowest content of exchangeable forms of this element was noted in all fractions of the cambic horizon $(\mathrm{Bw})$, whereas in fractions of deeper horizons there is a gradual increase of this cation with its maximal accumulation in carbonate horizons lying below the depth of $100 \mathrm{~cm}$.

The content of exchangeable magnesium gradually increases with decreasing the diameter of granulometric fractions and is much lower than that of calcium (Table 3$)$. Three sand fractions $(1-0.1 \mathrm{~mm})$ averagely bind only $0.5 \%$ of exchangeable magnesium, whereas the remaining fractions bind exchangeable magnesium at: $0.1-0.02 \mathrm{~mm}-5.2 \%, 0.02-0.002 \mathrm{~mm}$ - $40.7 \%$ and the clay fraction - $53.7 \%$ (Fig. 1). All fractions showed the lowest content of exchangeable magnesium in the cambic horizon, with the exception of fraction $<0.002 \mathrm{~mm}$ in diameter, and its content in particular fractions increased with larger depth of the soil profile.

Exchangeable potassium occurs in low amounts in fractions $>0.05 \mathrm{~mm}$, whereas gradual increase of 

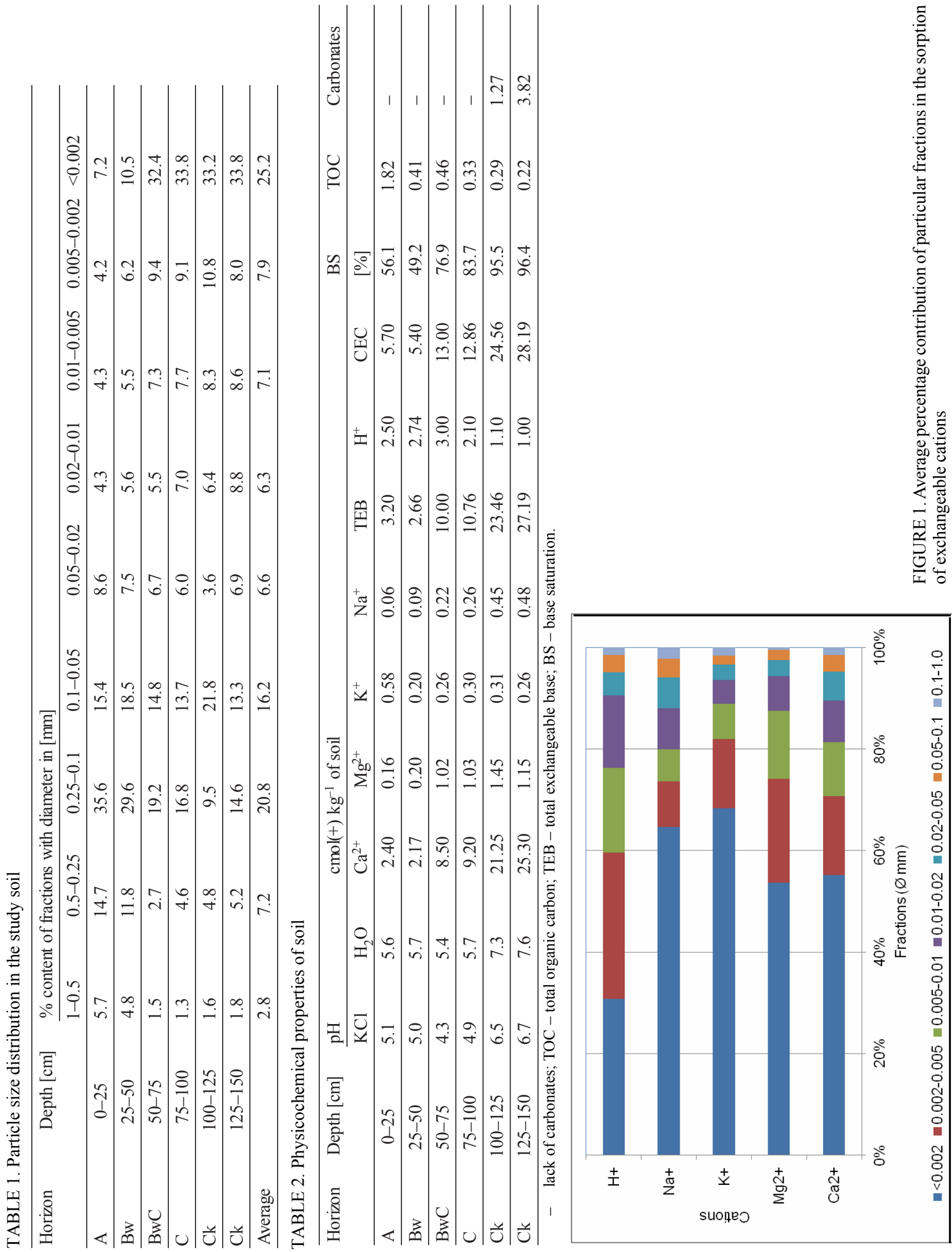
ل)

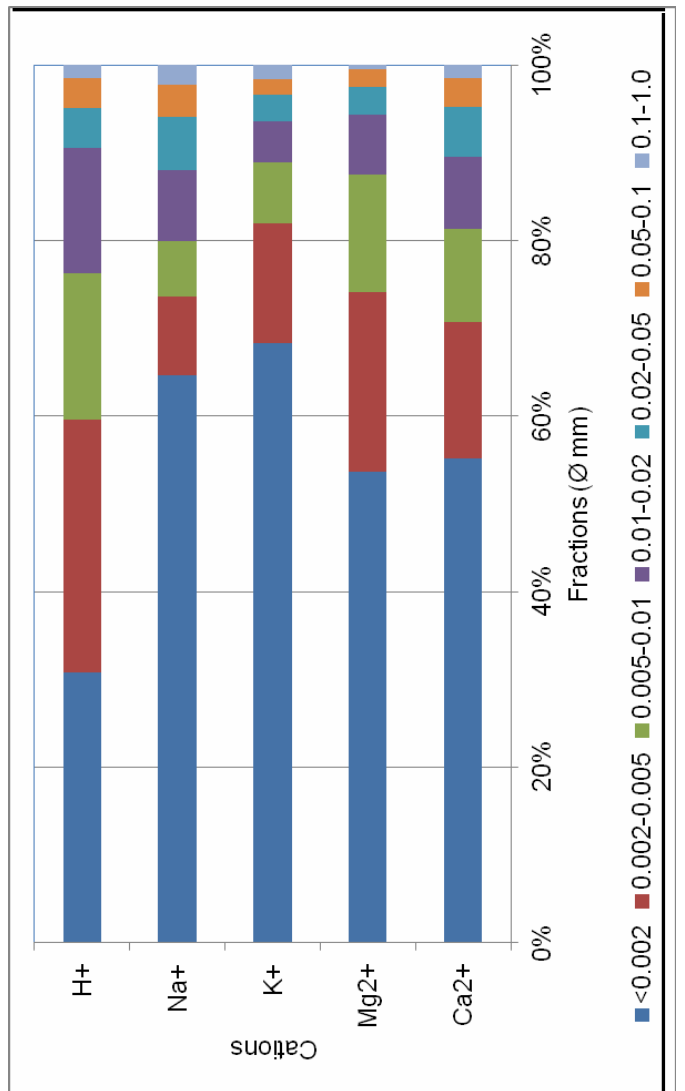




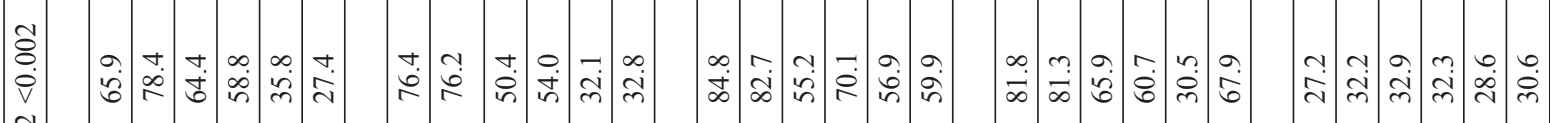

官

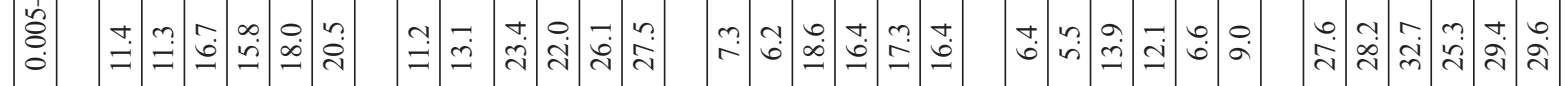

它

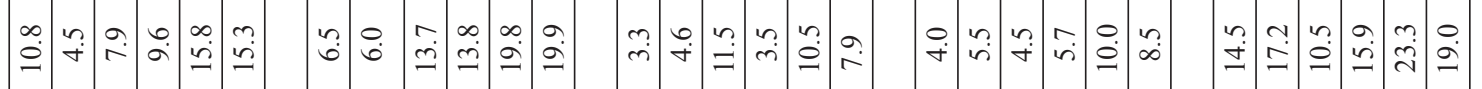

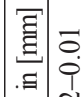

离

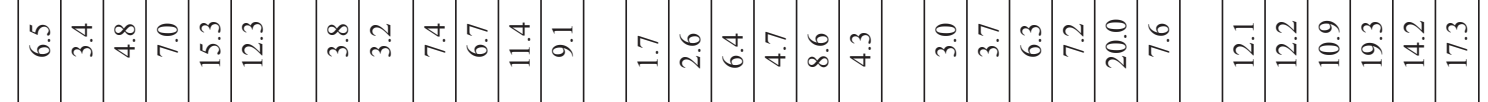
줄

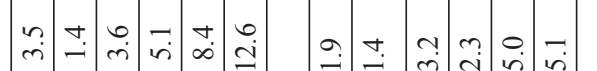

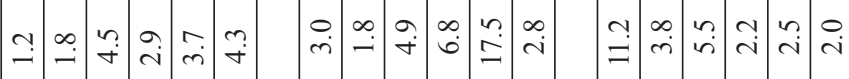

oิ

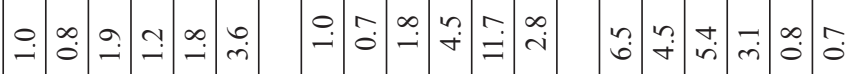

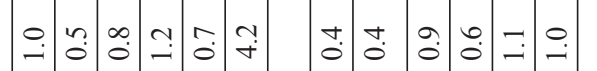

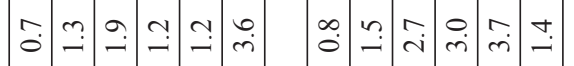

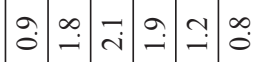

§ิ

8 ำ

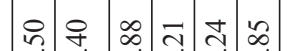

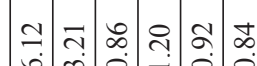

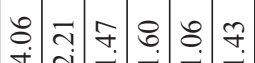

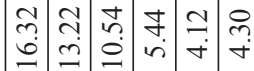

ชิ

(2)

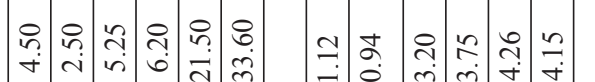

กิ่ ปึ

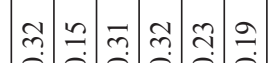

గ̂.

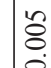

0
0
1
0
0
0
0

গิ

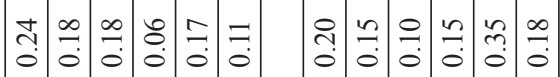

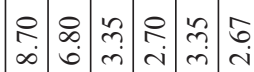

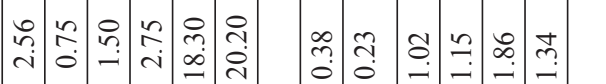

$\div \div \div \div$

눙

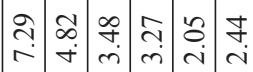

तै

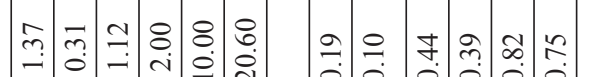

:

$\because \because=\infty$

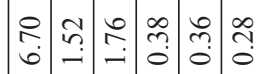

荧

퓽

ㄴำㅇำ

일

官管

:

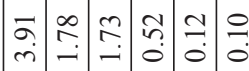

잉

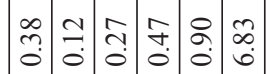

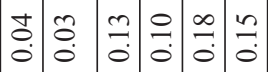

满

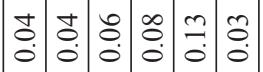

ڤn: 
its content is observed in $<0.05 \mathrm{~mm}$ fractions, with a maximal accumulation in the clay fraction (Table 3, Fig. 1). The percentage contribution of all granulometric fractions in the binding of this cation is averagely at: $1.0-0.05 \mathrm{~mm}-3.4 \%, 0.05-0.002 \mathrm{~mm}-28.4 \%$ and colloidal clay $-68.3 \%$. In the entire profile, all fractions from the humus horizon contain the largest amount of exchangeable potassium and its content decreases with depth, which points to lack of inward migration of this element.

At the depth of 100-125 cm, all granulometric fractions, with the exception of the clay fraction, are enriched in exchangeable sodium (Table 3, Fig. 1). At the same time, depletion in sodium is observed in the fractions from the cambic horizon, which points to leaching of this element, similarly as of calcium and magnesium.

The content of exchangeable hydrogen increases in the studied fractions with decreasing fraction size, but much less variably than in the case of the alkaline cations (Fig. 1, Table 3 ). The average contribution of fraction in its sorption is at: $1-0.02 \mathrm{~mm}-9.5 \%, 0.02-$ $0.002 \mathrm{~mm}-59.8 \%$ and for fraction $<0.002 \mathrm{~mm}-30.6 \%$. Notable is the much lower domination of the clay fraction in the binding of this cation in comparison to the alkaline cations. The highest contents of exchangeable hydrogen occur in all fractions of the surface humus horizon and decrease with depth. Gradual decrease of the content of exchangeable hydrogen in the entire profile, with small exceptions, was observed only for the $0.02-0.01$ and $0.01-0.005 \mathrm{~mm}$ fractions, whereas in the remaining fractions its content decreases to the depth of $75 \mathrm{~cm}$ gradually, to decrease rapidly below this depth.

The value of total exchangeable bases (TEB) increases successively with decreasing diameter of the granulometric fractions (Table 4). The average content of particular fractions in the sorption of alkaline cations is at: $1-0.05 \mathrm{~mm}-4.5 \%, 0.05-0.002 \mathrm{~mm}$ $-40.5 \%$ and $<0.002 \mathrm{~mm}-55.2 \%$. All fractions in the sub-surface cambic horizon showed the poorest possibilities of binding these cations, whereas their largest amounts occur in the deepest part of the profile, containing carbonates. Significant enrichment in exchangeable bases of the fractions from the surface horizon is caused by the presence of humus, and mineral and organic soil fertilization. Leaching has large influence on such distribution of the sorption properties of exchangeable bases by particular fractions. Enhancement of the leaching process significantly decreases with decreasing diameter of the granulometric fractions, with the exception of the $1-0.1 \mathrm{~mm}$ sand fraction (Fig. 2). There is a clear correlation between the decreasing dimension of the
$<0.1 \mathrm{~mm}$ fractions and the decreasing process of migration (leaching) of exchangeable bases from them (Fig. 3).

Cation exchange capacity increases with decrease of dimensions of the granulometric fractions (Table 5, Fig. 4 and 5). The average contribution of the granulometric fractions in the sorption capacity is at: $1-0.02 \mathrm{~mm}-11.7 \%$ (0.9 to $11.1 \%), 0.02-0.01 \mathrm{~mm}$ $-10.2 \%$ (7.7 to $14.8 \%$ ), $0.01-0.005 \mathrm{~mm}-12.8 \%$ (9.9 to $16.7 \%$ ), 0.005 $0.002 \mathrm{~mm}-20.5 \%$ (19.1\% to $24.1 \%$ ) and fraction $<0.002 \mathrm{~mm}-$ $44.8 \%$, varying from 28.8 to $54.4 \%$ in the soil profile. The largest capacity is observed for all fractions from the deepest part of the profile where carbonates are present $(<100 \mathrm{~cm})$; it is much lower in the humus horizon, and the lowest in fractions from the middle part of the profile (between 25 and $100 \mathrm{~cm}$ ). Such diversified sorption capacity results from mineral composition, content of humus compounds, iron and aluminium oxides, and the presence and solubility of carbonates.

Calcium and hydrogen have the largest contribution in the exchangeable sorption capacity of all fractions (Fig. 6, Table 6). In contrast to the remaining fractions, the clay fraction is characterised by the largest contribution of calcium and clearly the lowest contribution of hydrogen

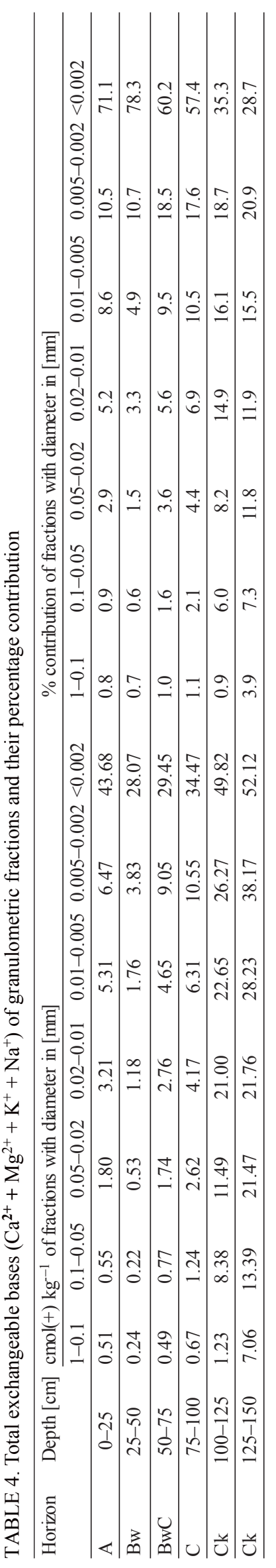


TABLE 5. Cation exchange capacity (CEC) of granulometric fractions

\begin{tabular}{lcccccccc}
\hline Horizon & Depth $[\mathrm{cm}]$ & \multicolumn{2}{c}{$\mathrm{cmol}^{(+)} \mathrm{kg}^{-1}$ of fractions with diameter in $[\mathrm{mm}]$} \\
\cline { 3 - 9 } & & $1-0.1$ & $0.1-0.05$ & $0.05-0.02$ & $0.02-0.01$ & $0.01-0.005$ & $0.005-0.002<0.002$ \\
\hline $\mathrm{A}$ & $0-25$ & 1.06 & 4.46 & 8.50 & 10.50 & 14.01 & 23.30 & 60.00 \\
\hline $\mathrm{Bw}$ & $25-50$ & 0.97 & 2.04 & 2.05 & 6.00 & 8.56 & 15.00 & 41.30 \\
\hline $\mathrm{BwC}$ & $50-75$ & 1.15 & 2.50 & 3.50 & 6.24 & 8.00 & 19.50 & 40.00 \\
\hline $\mathrm{C}$ & $75-100$ & 1.00 & 1.76 & 3.03 & 7.44 & 9.00 & 14.83 & 40.45 \\
\hline $\mathrm{Ck}$ & $100-125$ & 1.40 & 8.50 & 11.85 & 23.04 & 26.00 & 30.50 & 53.94 \\
\hline $\mathrm{Ck}$ & $125-150$ & 7.18 & 13.49 & 21.75 & 24.20 & 30.88 & 42.25 & 56.42 \\
\hline
\end{tabular}

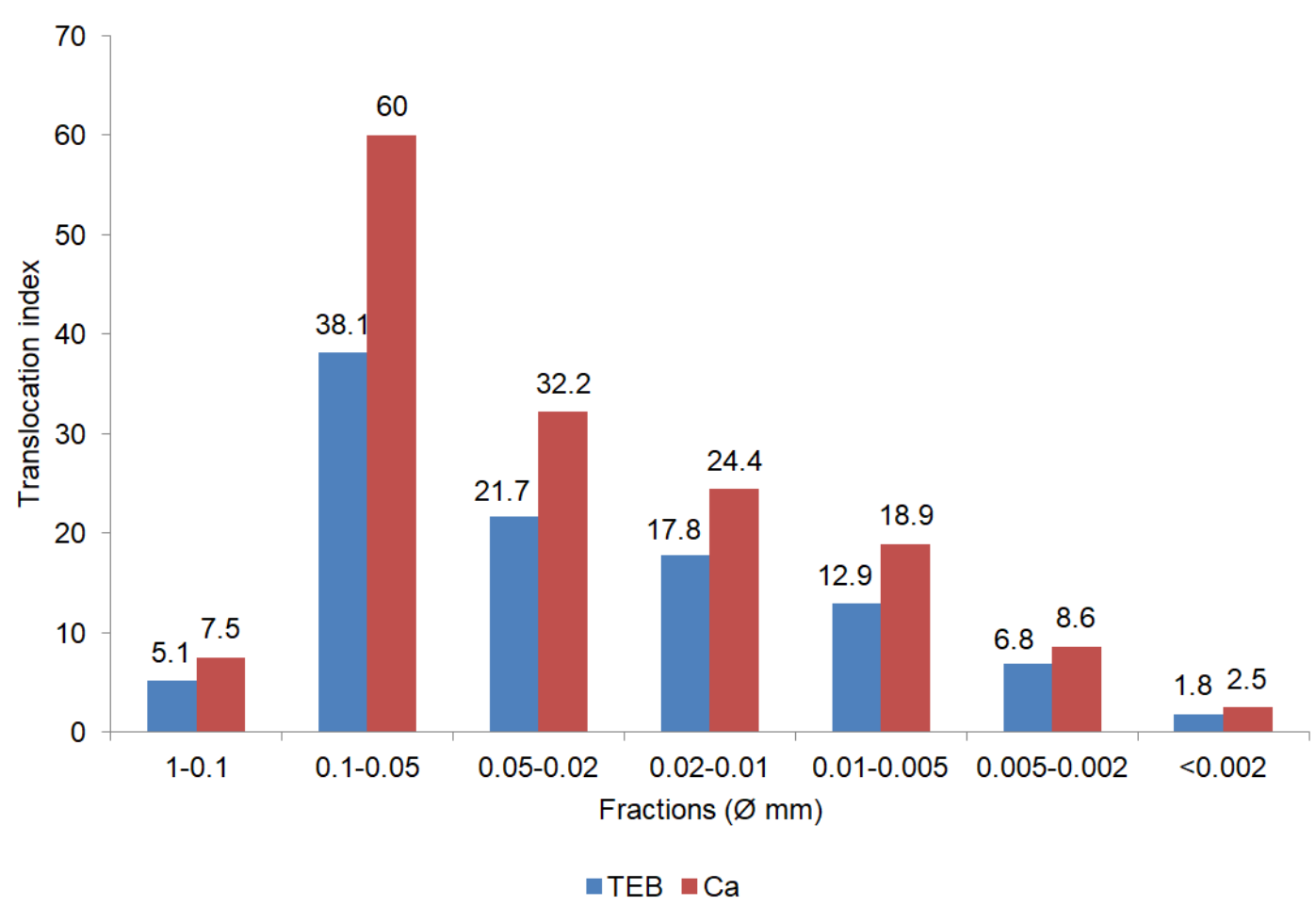

FIGURE 2. Translocation index of total exchangeable bases (TEB) and calcium cations (Ca) in particular granulometric fractions (translocation index TEB $=$ TEB content in the first $\mathrm{Ck}$ horizon $/ \mathrm{TEB}$ content in the $\mathrm{Bw}$ horizon; translocation index $\mathrm{Ca}=\mathrm{Ca}$ content in the first $\mathrm{Ck}$ horizon / $\mathrm{Ca}$ content in the $\mathrm{Bw}$ horizon)

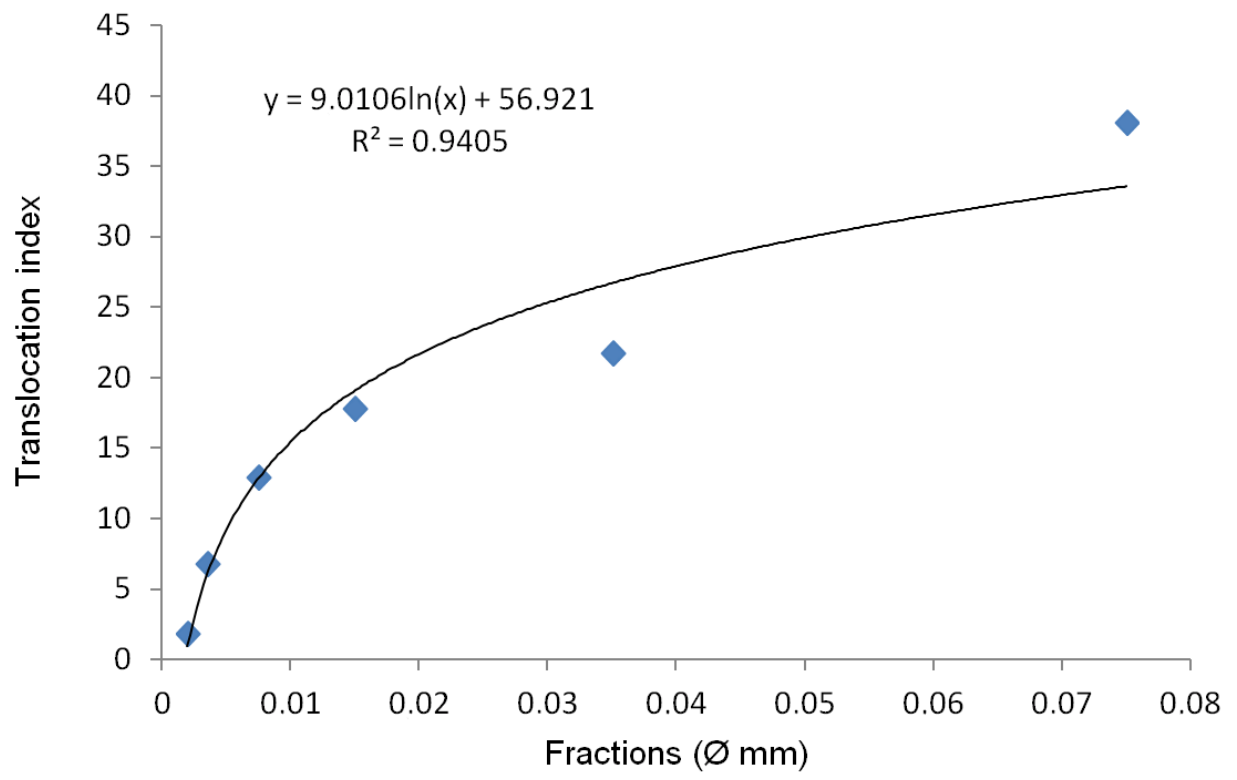

FIGURE 3. Relationship between $<0.1 \mathrm{~mm}$ fractions and translocation of total exchangeable bases 


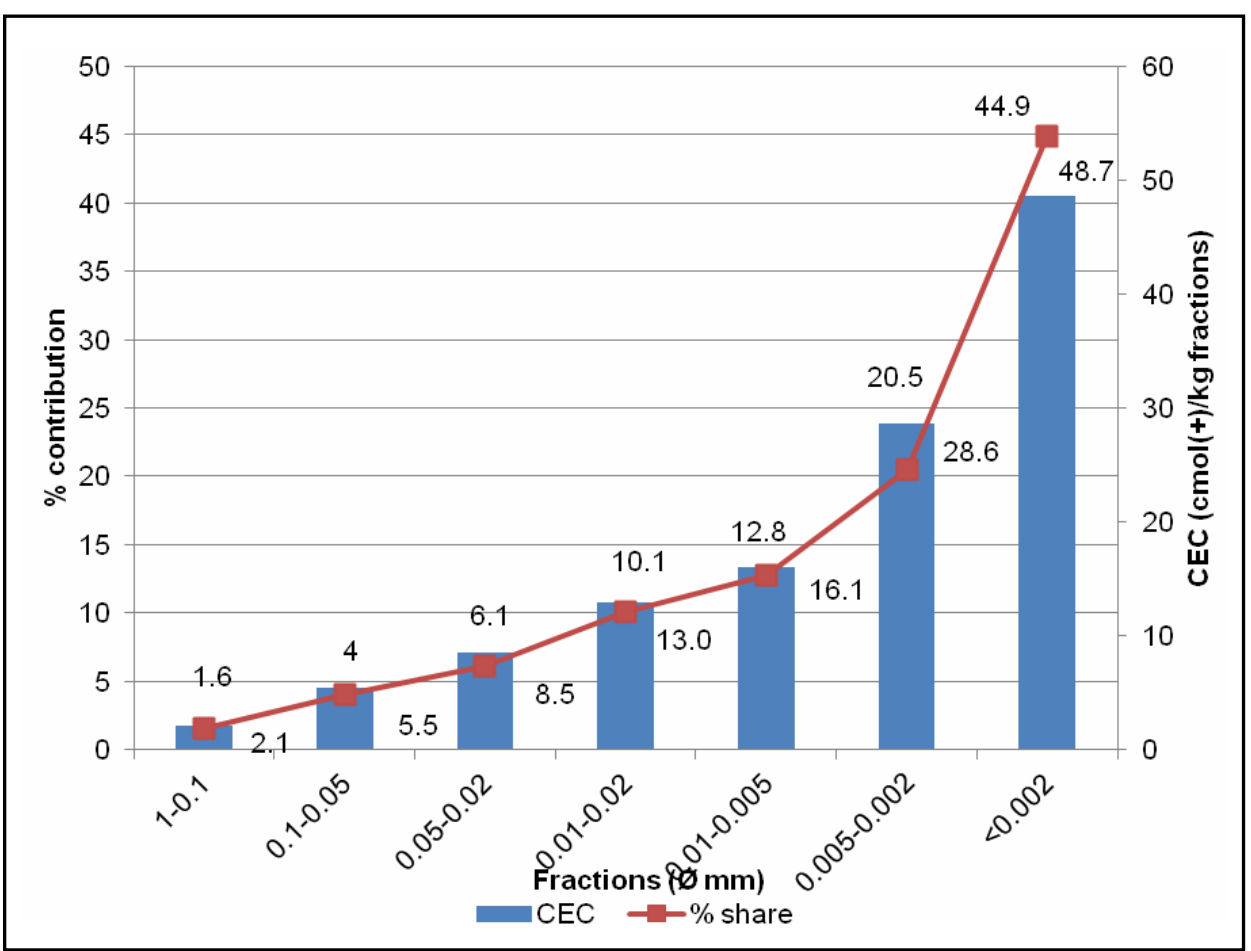

FIGURE 4. Average cation exchange capacity of particular fractions and their \% contribution

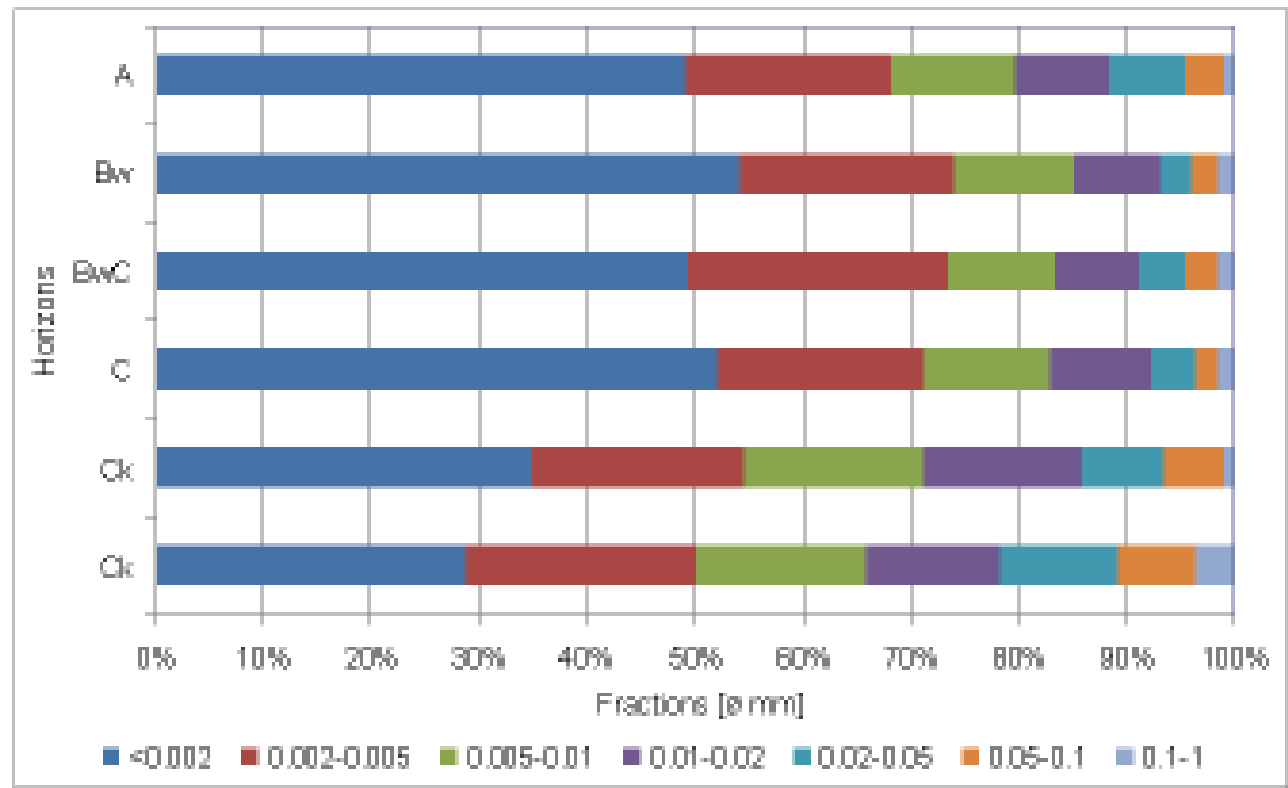

FIGURE 5. Percentage contribution of particular fractions in the cation exchange capacity

in the sorption complex. With decrease of fraction dimensions, the average contents of magnesium and potassium + sodium increase, with the exception of the $1-0.02 \mathrm{~mm}$ fraction. With depth, in all granulometric fractions from subsequent horizons and layers, the content of calcium increased whereas the content of hydrogen decreased (Table 6). The average content of particular cations in the fractions is arran- ged as follows to the depth of $75 \mathrm{~cm}: \mathrm{H}^{+}>\mathrm{Ca}^{2+}>$ $\mathrm{Mg}^{2+}>\mathrm{K}^{+}+\mathrm{Na}^{+}$, and in the deeper part of the profile: $\mathrm{Ca}^{2+}>\mathrm{H}^{+}>\mathrm{Mg}^{2+}>\mathrm{Na}^{+}+\mathrm{K}^{+}$. Such distribution of exchangeable cations is caused by the influence of leaching in the studied soil, whose intensity, with some exceptions, decreases with decrease of fraction diameter. 

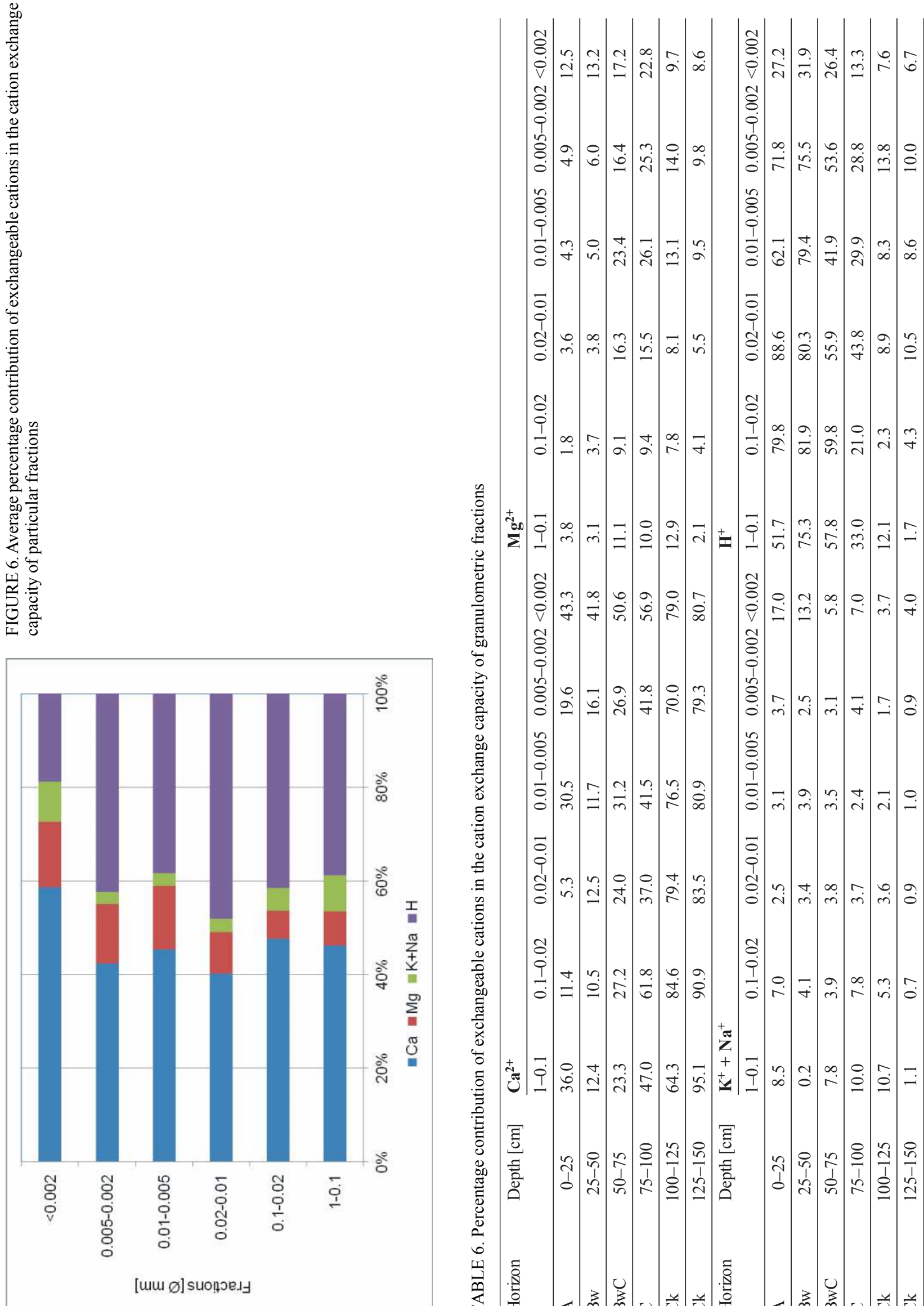

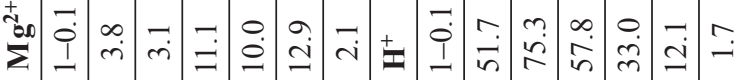

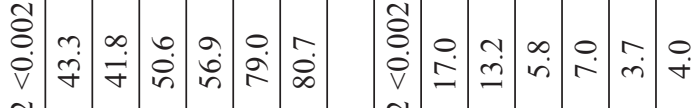
ठิ

高管

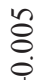

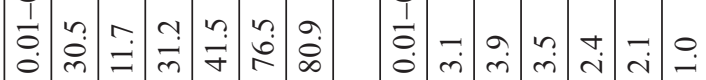

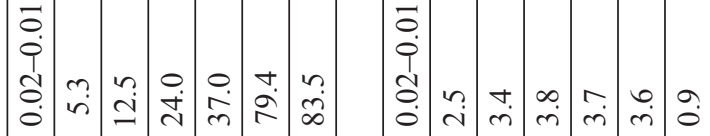

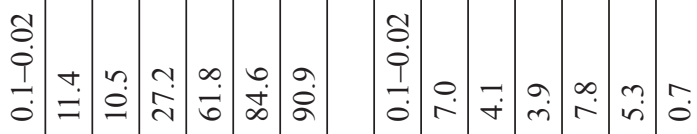
榜

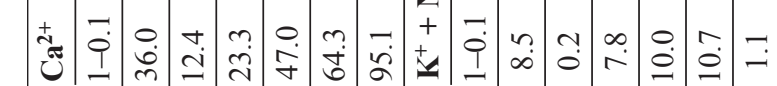

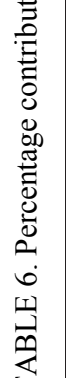
胥

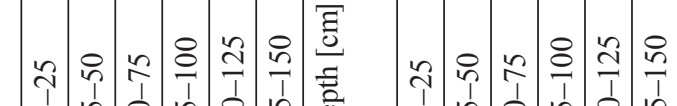

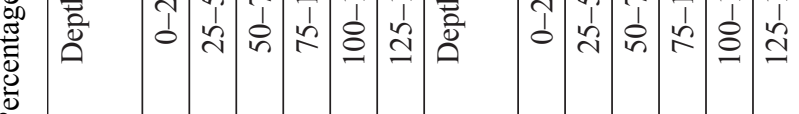

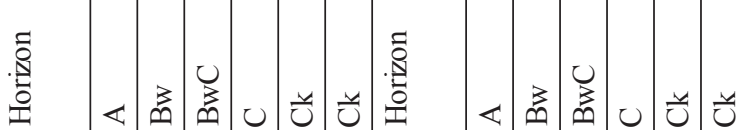




\section{DISCUSSION}

Literature data and individual investigations indicate that the sorption properties of the granulometric fractions depend on their mineral composition - particularly the presence of clay minerals, humus compounds, and iron and aluminium oxides (Asadu et al. 1997, McAleese and Mitchell 1958; Morrás 1995, Soares et al. 2005, Tedrow 1966). A large role is attributed also to the origin and properties of the parent rock (mineral composition, susceptibility to weathering), pedogenic processes and climate conditions influencing the intensity of weathering processes. The obtained values of cation exchange capacity (CEC) in the granulometric fractions and the regularity of increasing sorption capacity of particular fractions with decrease of their diameter are similar to earlier results of studies on fractions selected from soils developed from sands and loams in Poland (Okołowicz 1996). Similar sorption properties of granulometric fractions were also obtained for soils developed from limestones of Ireland (McAleese and McConaghy 1957), Germany (Leinweber et al. 1993), USA (Joffe and Kunin 1943) and Spain (Caravaca et al. 1999). Partly different results, with a much larger sorption capacity of the silt fraction than in the studied soil were obtained for some soils of Ireland (McAleese and Mitchell 1958), Africa (Asadu et al. 1997), Argentina (Morrás 1995) and USA (Tedrow 1966). In turn, studies of Soares et al. (2005) on some soils of Brasil have indicated a much larger sorption capacity for both silts and sands.

Rapid increase of exchangeable sorption capacity was observed in all fractions and soil in the lower part of the profile with carbonates, which was caused mainly by the increased content of calcium. It may be the result of partial extraction of calcium from carbonates during determination of base cations. Calcium is easiest removed from active carbonates, relatively recently leached from the upper parts of the analysed profile. The phenomenon of very high exchangeable sorption capacity in soil horizons with carbonates was also observed in soils of Roztocze Hills, the Holy Cross Mountains (Kuźnicki 1965, Kuźnicki et al. 1976), and Lower Silesia (Licznar 1976), and in rendzina soils from different geological formations (Zagórski 2003) in Poland. Similar results were obtained in carbonate profiles from Argentina by Bockheim and Douglass (2006) and from Brazil by Silva et al. (2017). The phenomenon of very high exchangeable sorption capacity of fractions in horizons with carbonates may also result from their different mineral composition and the presence of mineral amorphous substances, so far rarely included in the sorption capacity (alophane, imogolite, ferrihydrite).

Leaching, commonly taking place in Polish soils (Chojnicki 2002, Kozłowski and Komisarek 2017a; Markiewicz et al. 2017), has large influence on the diversity of sorption properties of granulometric fractions. The process concerns leaching of calcium carbonate, exchangeable cations, clay minerals and available nutrients (Le and Marschner 2018) from surface horizons to deeper horizons. Studies indicate that leaching of exchangeable calcium and total exchangeable cations is the highest in the $0.1-0.05 \mathrm{~mm}$ fraction, to decrease successively and statistically significantly with decrease of fraction diameter, with the exception of the 1-0.1 mm sand fraction (Fig. 2 and 3). Calcium is most susceptible to leaching, whereas magnesium and sodium much less; in turn, potassium was not leached at all. The phenomenon well explains the high susceptibility of light and medium soils to leaching, due to their large permeability and high contribution of coarse fractions.

\section{CONCLUSIONS}

1. The exchangeable sorption capacity of granulometric fractions successively increased with decrease of their diameter, and its average values in cmol( $(+) \mathrm{kg}^{-1}$ and percentage contribution for particular fractions were: $1-0.1 \mathrm{~mm}-2.1(1.6 \%), 0.1-$ $0.05 \mathrm{~mm}-5.5(4.0 \%), 0.05-0.02 \mathrm{~mm}-8.5(6.1 \%)$, $0.02-0.01-13.0(10.1 \%), 0.01-0.005 \mathrm{~mm}-16.1$ (12,8\%), 0.005-0.002 mm - $28.6(20.5 \%)$, and fraction $<0.002 \mathrm{~mm}-48.7(44.9 \%)$.

2. The dominating cations in the sorption complex of particular granulometric fractions were calcium and exchangeable hydrogen, and leaching caused that the contribution of cations in particular fractions was arranged as: $\mathrm{H}^{+}>\mathrm{Ca}^{2+}>\mathrm{Mg}^{2+}>\mathrm{K}^{+}$ $+\mathrm{Na}^{+}$in the upper part of the profile, and as: $\mathrm{Ca}^{2+}$ $>\mathrm{H}^{+}>\mathrm{Mg}^{2+}>\mathrm{Na}^{+}+\mathrm{K}^{+}$in the deeper part of the profile.

3. Leaching of base exchangeable cations was the largest in the $0.1-0.05 \mathrm{~mm}$ fraction and successively decreased with decrease of fraction diameter, whereas the sand fraction $1-0.1 \mathrm{~mm}$ had a low susceptibility to this process. Calcium was most leached, magnesium and sodium - much less, whereas potassium did not undergo this process.

4. Rapid increase of the exchangeable sorption capacity in fractions from carbonate horizons was caused by increase of the content of calcium cations, which could be released from the carbonates during extraction of base cations. 


\section{REFERENCES}

Asadu C.L.A., Diels J., Vanlauwe B., 1997. A comparison of the contributions of clay, silt, and organic matter to the effective CEC of soils of Subsaharan Africa. Soil Sci. 162(11): 785794.

Bockheim J., Douglass D., 2006. Origin and significance of calcium carbonate in soils of southwestern Patagonia. Geoderma 136(3-4): 751-762.

Brogowski Z., Kwasowski W., 2015. An attempt of using soil grain size in calculating the capacity of water unavailable to plants. Soil Sci. Ann. 66(1): 21-28.

Brogowski Z., Kocoń J., 1984. Morphology of surface of sand grains from different genetic horizons of brown soil developed from heavy loam. Rocz. Glebozn. - Soil Sci. Ann. 35(1): 115124.

Caravaca F., Lax A., Albaladejo J., 1999. Organic matter, nutrient contents and cation exchange capacity in fine fractions from semiarid calcareous soils. Geoderma 93(3-4): 161-176.

Chojnicki J., 2002. Soil-forming processes in alluvial soils of central Vistula valley and Żuławy. Wyd. SGGW, Warszawa: $83 \mathrm{pp}$.

Czaban J., Czyż E., Siebielec G., Niedźwiecki J., 2014. Longlasting effects of bentonite on properties of a sandy soil deprived of the humus layer. Int. Agrophys. 28: 279-289.

Dąbkowska-Naskręt H., Różański S., Bartkowiak A., 2016. Forms and mobility of trace elements in soils of park areas from the city of Bydgoszcz, north Poland. Soil Sci. Ann. 67(2): 73-78.

Francaviglia R., Carroni A., Bazzoffi P., Troccoli A., Borrelli L., Napoli R., Ventrella D., Montemurro F., Chiarini F., 2016. Testing the effectiveness of the European cross-compliance standard 3.1 "Ploughing in Good Soil Moisture Conditions". Int. J. Environ. Res. 10(4): 655-666.

IUSS Working Group WRB, 2015. World Reference Base for Soil Resources 2014, update 2015. International soil classification system for naming soils and creating legends for soil maps. World Soil Resources Reports No. 106. FAO, Rome.

Jahn R., Blume H.P., Asio V.B., et al. 2006. Guidelines for Soil Description. FAO, Rome: 97 pp.

Joffe J., Kunin R., 1943. Mechanical separates and their fractions in the soil profile. II. The cation exchange properties and pedogenic implications. Soil Sci. Soc. Am. Proc. 8: 384 387.

Kalembasa D., Pakuła K., Jaremko D., 2011. Sorption properties of soils in the Siedlce upland. Acta Agrophysica 18(2): 311319 (in Polish with English summary).

Korobova E., Linnik V., Chizhikova N., Alekseeva T., Shkinev V., Brown J., Dinu M., 2014. Granulometric and mineralogic investigation for explanation of radionuclide accumulation in different size fractions of the Yenisey floodplain soils. Journal of Geochemical Exploration 142: 49-59.

Kozłowski M., Komisarek J., 2017a. Textural diversity in selected Retisols in the catenaof the Opalenica Plain (western Poland). Soil Sci. Ann. 68(1): 1-18.

Kozłowski M., Komisarek J., 2017b. Analysis of the suitability of Polish soil texture classification for estimating soil water retention and hydraulic properties. Soil Sci. Ann. 68(4): 197204.

Kuźnicki F., 1965. Properties and typology of soils from cretaceous decalcified siliceous rock of Roztocze region in relation to characteristics and genetic division of rendzinas. Rocz. Glebozn. - Soil Sci. Ann. 15(2): 345-408.

Kuźnicki F., Białousz S., Kamińska H., Oszmiańska M., Skłodowski P., Ziemińska A., Żakowska H., 1976. Rendzina soils developed from carbonate rocks of different geological formations over the area of the Świętokrzyskie mountains and their borderings. Rocz. Glebozn. - Soil Sci. Ann. 27(2): 1948.

Le T.H.X., Marschner P., 2018. Mixing organic amendments with high and low $\mathrm{C} / \mathrm{N}$ ratio influences nutrient availability and leaching in sandy soil. J. Soil Sci. Plant Nutr. 18: 952-964.

Leinweber P., Reuter G., Brozio K., 1993. Cation exchange capacities of organo-mineral particle-size fractions in soils from long-term experiments. J. Soil Sci. 44: 111-119.

Licznar S., 1976. Rendzinas and soils on limestone of the Opole region in the light of micromorphological and physicochemical investigations. Rocz. Glebozn. - Soil Sci. Ann. 27(3): 73-121.

Malik Z., Malik M., Yu-Tong Z., and Sheng-Gao L., 2014. Physical properties of unproductive soils of Northern China. Int. Agrophys. 28: 459-469.

Markiewicz M., Gonet S., Marszelewski W., Mendyk Ł., Sykuła M., 2017. Differentiation of soils and land use changes in the vicinity of the disappeared Gardeja lake (Northern Poland). Soil Sci. Ann. 68(3): 115-124.

Martins E., Melo V., Bohone J., Gilberto Abate G., 2018. Sorption and desorption of atrazine on soils: The effect of different soil fractions. Geoderma 322: 131-139.

McAleese D., McConaghy S., 1957. Studies on the basaltic soils of Northern Ireland. II. Contributions from the sand, silt and clay separates to cation exchange properties. J. Soil Sci. 8(1): 135-140.

McAleese D., Mitchell W.A., 1958. Studies on the basaltic soils of Northern Ireland: V. Cation-exchange capacities and mineralogy of the silt separates (2-20 $\mu$ ). J. Soil Sci. 9(1): 81-88.

Morrás H.J.M., 1995. Mineralogy and cation exchange capacity of the fine silt fraction in two soils from the southern Chaco Region Argentina. Geoderma 64: 281-295.

Musztyfaga E., Kabała C., 2015. Lithological discontinuity in Glossic Planosols (Albeluvisols) of Lower Silesia (SW Poland). Soil Sci. Ann. 66(4): 180-190.

Okołowicz M., 1996. Sorption capacity of particle size fractions of selected soils. Rocz. Glebozn. - Soil Sci. Ann. 47(1-2): $33-46$.

Rafraf S., Guellouz L., Guiras H., Bouhlila R. 2016. Quantification of hysteresis effects on a soil subjected to drying and wetting cycles. Int. Agrophys. 30: 493-499.

Rastegari M., Saeedi M., Mollahosseini A., Ayatinia M., 2016. Phenanthrene sorption onto kaolinite; Heavy Metals and Organic Matter Effects. Int. J. Environ. Res. 10, 3: 441-448.

Roth E., Mancier V., Fabre B., 2012. Adsorption of cadmium on different granulometric soil fractions: Influence of organic matter and temperature. Geoderma 189-190: 133-143.

Silva M., Anjos L., Pereira M., Schiavo J., Cavassani R., 2017. Soils in the karst landscape of Bodoquena plateau in cerrado region of Brazil. Catena 154: 107-117.

Singh B., Farenhorst A., Gaultier J., Pennock D., Degenhardt D., McQueen R., 2014. Soil characteristics and herbicide sorption coefficients in 140 soil profiles of two irregular undulating to hummocky terrains of western Canada. Geoderma 232: 107-116. 
Skic K., Boguta P., Sokołowska Z., 2016. Analysis of the sorption properties of different soils using water vapour adsorption and potentiometric titration methods. Int. Agrophys. 30: 369-374.

Soares M., Alleoni L., Vidal-Torrado P., Cooper M., 2005. Mineralogy and ion exchange properties of the particle size fractions of some Brazilian soils in tropical humid areas. Geoderma 125: 355-367.

Stemmer M., Gerzabek M.H., Kandeler E., 1998. Organic matter and enzyme activity in particle-size fractions of soils obtained after low-energy sonication. Soil Biol. Biochem. 30: $9-17$.
Tedrow J.C.F., 1966. Properties of sand and silt fractions in New Jersey soils. Soil Sci. 101(1): 24-30.

USDA SCS. 1992. Soil survey laboratory methods manual. Soil Survey Investigation Report No 42. Version 2.0.

van Reeuwijk L.P., 1992. Procedures for Soil Analysis. International Soil Reference and Information Centre, Wageningen, The Netherlands: $100 \mathrm{pp}$.

Zagórski Z., 2003. Mineralogical and micromorphological indicators of the origin and properties of rendzina soils developed from carbonate rocks of different geological formations. Wyd. Fundacja „Rozwój SGGW”. Warszawa: 124 pp.

Received: April 19, 2019

Accepted: June 28, 2019

Associated editor: A. Lachacz

\section{Właściwości sorpcyjne frakcji granulometrycznych w glebie brunatnej wylugowanej wytworzonej z gliny zwalowej}

Streszczenie: Celem pracy było zbadanie właściwości sorpcyjnych frakcji granulometrycznych, wydzielonych z poziomów genetycznych uprawnej gleby brunatnej wyługowanej, wytworzonej z gliny zwałowej zlodowacenia środkowopolskiego stadiału Warty. Wydzielenie frakcji przeprowadzono metodą Atterberga bez wirowania i stosowania peptyzatorów. Wymienna pojemność sorpcyjna frakcji granulometrycznych zwiększała się wraz ze zmniejszaniem się ich średnicy, a średnia jej wartość w cmol $(+) \mathrm{kg}^{-1}$ i udział w poszczególnych frakcjach wynosiła: $1-0,1 \mathrm{~mm}-2,1(1,6 \%), 0,1-0,05 \mathrm{~mm}-5,5(4,0 \%), 0,05-0,02 \mathrm{~mm}-8,5(6,1 \%)$, 0,02-0,01-13,0 (10.1\%), 0,01-0,005 mm - 16,1 (12,8\%), 0,005-0,002 mm - 28,6 (20,5\%) oraz frakcji <0,002 mm - 48,7 (44,9\%). Proces wymywania zasadowych kationów wymiennych był największy we frakcji $0,1-0,05 \mathrm{~mm}$ i sukcesywnie zmniejszał się wraz ze zmniejszaniem się średnicy frakcji. Najbardziej ługowaniu ulegał wapń, znacznie mniej magnez i sód, a potas nie podlegał temu procesowi. Znaczne zwiększenie wymiennej pojemności sorpcyjnej we frakcjach z poziomów węglanowych było spowodowane przede wszystkim zwiększeniem zawartości kationu wapnia, który mógł być uwalniany z węglanów przy ekstrakcji kationów zasadowych.

Słowa kluczowe: frakcje granulometryczne, wymienna pojemność sorpcyjna, ługowanie 